\title{
ANALISIS EFISIENSI USAHATANI PADI SAWAH LAHAN RAWA DI KABUPATEN CIAMIS (Suatu Kasus di Kecamatan Lakbok Kabupaten Ciamis)
}

\section{ANALYSIS OF PADDY FARMING EFFICIENCY OF SWAMP LAND IN CIAMIS DISTRICT (A Case in Lakbok Subdistrict, Ciamis District)}

\author{
T. Syaiful Azwar*, Trisna Insan Noor, Ernah \\ Program Studi Pasca Sarjana Universitas Padjadjaran \\ Jl. Raya Bandung Sumedang KM 21, Jatinangor 45363, Telepon/Fax: (022) 7796316 \\ *Email: tengkusaiful83@gmail.com \\ (Diterima 04-07-2019; Disetujui 22-07-2019)
}

\begin{abstract}
ABSTRAK
Identifikasi masalah penelitian ini adalah: 1) Bagaimana keragaan usahatani padi sawah di Kecamatan Lakbok? 2) Adakah pengaruh penggunaan faktor-faktor produksi secara bersama-sama (simultan) dan secara sendiri-sendiri (parsial) terhadap hasil produksi usahatani padi sawah di Kecamatan Lakbok ? 3) Apakah rata-rata penggunaan faktor-faktor produksi pada usahatani padi sudah efisien atau belum ? Uji analisis dengan menggunakan analisis regresi berganda dengan sampel 98 orang petani responden yang ada di Kecamatan Lakbok Kabupaten Ciamis. Pengambilan sampel dilakukan dengan Cluster Sampling. Data yang dikumpulkan dianalisis dengan menggunakan pendekatan deskriptif kuantitatif dan Analisis Efisiensi Ekonomi Faktor Produksi. Hasil penelitian menunjukan bahwa: 1) Rata-rata hasil produksi padi yang diperoleh di Kecamatan Lakbok sebanyak $3.600 \mathrm{~kg} / \mathrm{ha}$ GKG. Sedangkan total pendapatan untuk petani di Kecamatan Lakbok sebesar Rp 7.197.137,37 per hektar per musim tanam dengan RC rasio 1,80 per musim tanam. 2) Besar determinasi $\left(\mathrm{R}^{2}\right)$ adalah sebesar 0,913. Hal ini dapat diartikan bahwa variabel independen (luas lahan, benih, pupuk, pestisida, fungisida, insektisida dan tenaga kerja) dapat menjelaskan variabel dependen (produksi padi) sebesar 91,1 persen, sedangkan sisanya diterangkan oleh faktor lain di luar model yang diturunkan. Sedangkan nilai koefisien determinasi diperoleh nilai sebesar 0,958 artinya keeratan hubungan antara variabel independen dan variabel dependen sebesar 95,8 persen. 3) Luas lahan, fungisida, insektisida dan tenaga kerja lebih besar dari satu, artinya kombinasi penggunaan faktor produksi yang berupa luas lahan, fungisida, insektisida dan tenaga kerja pada usahatani padi sawah belum mencapai efisiensi ekonomi. Sedangkan nilai efisiensi ekonomi untuk faktor produksi benih dan pestisida menunjukkan angka negatif, artinya penggunaan faktor produksi tersebut pada usahatani padi sudah terlalu banyak dan akan mengurangi tingkat pendapatan yang diperoleh.
\end{abstract}

Kata kunci: Usahatani padi sawah, Produktivitas, Efisiensi Produksi

\section{ABSTRACT}

The identification of the problem of this research are: 1) How is the performance of wetland rice farming in Lakbok Subdistrict? 2) Is there influence on the use of production factors together (simultaneously) and individually (partially) on the production of rice paddies in Lakbok Subdistrict? 3) Is the average use of production factors on rice farming efficient or not? Test analysis using multiple regression analysis with a sample of 98 respondent farmers in Lakbok District, Ciamis Regency. Sampling is done by cluster sampling. The collected data were analyzed using quantitative descriptive approach and Production Factor Economic Efficiency Analysis. The results showed that: 1) The average yield of rice produced in Lakbok Subdistrict was 3,600 Kg / Ha MPD. While the total income for farmers in Lakbok District is Rp. 7,197,137.37 per hectare per planting season with $R C$ ratio of 1.80 per planting season. 2) The amount of determination (R2) is 0.913. This can be interpreted that the independent variables (land area, seeds, fertilizers, 
pesticides, fungicides, insecticides and labor) can explain the dependent variable (rice production) of 91.1 percent, while the remainder is explained by other factors outside the derived model. While the value of the coefficient of determination obtained value of 0.958 means that the closeness of the relationship between the independent variable and the dependent variable is 95.8 percent. 3) The area of land, fungicides, insecticides and labor is greater than one, meaning that the combination of the use of production factors in the form of land area, fungicide, insecticide and labor in lowland rice farming has not been economic efficiency. While the value of economic efficiency for factors of seed and pesticide production shows a negative number, meaning that the use of production factors in rice farming is too much and will reduce the level of income earned.

Keywords: Lowland Rice Farming, Productivity, Production Efficiency

\section{PENDAHULUAN}

Padi masih menjadi komoditas penting dalam kebijakan pertanian di indonesia karena terkait dengan ketahanan pangan dan swasembada beras. Dalam rangka sustainability swasembada beras, selain demand side pembenahan supply side dianggap masih relevan (Kusnadi, 2011). Pembenahan supply side yang lebih diutamakan saat ini seharusnya mengarah pada peningkatan produktivitas melalui intensifikasi daripada perluasan lahan. Hal ini karena hingga kini dan beberapa tahun ke depan diduga pertumbuhan produktivitas padi masih mengalami kemandegan (levelingoff) namun masih lebih tinggi dari pertumbuhan perluasan lahan, sehingga peningkatan produksi lebih didukung oleh pertumbuhan produktivitas daripada luas areal.

Luas lahan pasang surut di Indonesia diperkirakan 20,10 juta ha, sekitar $20-30 \%$ di antaranya berpotensi untuk digunakan sebagai lahan pertanian. Sampai saat ini baru sekitar 3-4 juta ha lahan rawa yang sudah direklamasi. Pembukaan lahan rawa pasang surut memerlukan perencanaan yang matang dan hati-hati supaya tidak mengalami kegagalan, karena lahan rawa bersifat rapuh (fragile).

Dalam menentukan jenis-jenis lahan rawa yang berpotensi untuk pertanian perlu dilakukan identifikasi dan karakterisasi wilayah rawa pasang surut yang akan dikembangkan. Pada lahan rawa pasang surut biasa ditemukan tanah gambut dan tanah mineral. Pada tanah mineral biasa, ditemukan tanah mineral yang belum matang dan matang. Tanah mineral matang umumnya sudah mengalami pengolahan lahan atau dibuat saluran-saluran. Pada tanah mineral ini dijumpai beberapa jenis tipologi lahan, yaitu tanah sulfat masam potensial, tanah sulfat masam aktual.

Lahan rawa non pasang surut, atau 
sering disebut rawa lebak, memiliki kekuatan arus pasang dari laut jauh lebih kecil (atau bahkan sudah tidak tampak sama sekali) daripada kekuatan arus dari hulu sungai. Pada zona ini, pengaruh kekuatan arus sungai jauh lebih dominan. Tanda pasang surut harian yang biasanya tampak sebagai gerakan naik turunnya air sungai, sudah tidak nampak lagi. Sejak batas dimana gerak naik turunnya air tanah tidak terlihat lagi, maka lahan rawa pada lokasi ini termasuk sebagai rawa non pasang surut atau lahan rawa lebak (Anwar et al, 2006). Beberapa permasalahan usahatani padi sawah yang dihadapi oleh petani padi sawah di Kecamatan Lakbok sebagai sentra produksi padi Kabupaten Ciamis antara lain: lahan areal sawah belum teraliri dengan irigasi teknis, belum adanya benih yang cocok dengan areal persawahan rawa, sering terdapat serangan pengganggu tumbuhan serta hama penyakit pada musim pancaroba (Hujan) yang dapat menurunkan kuantitas dan kualitas produksi, petani belum sepenuhnya menerapkan Good Agriculture Practices (GAP), dan penggunaan faktor-faktor produksi yang belum sesuai (BP3K Kecamatan Lakbok, 2016). Hal-hal tersebut dapat mengakibatkan terdapatnya inefisiensi teknis yang terjadi apabila suatu unit produksi tidak dapat menghasilkan output optimum dari faktor produksi yang digunakan.

Penggunaan faktor produksi yang tidak efisien akan berpengaruh pada tingkat produktivitas usahatani. Kemampuan petani dalam melakukan pengelolaan dan pengalokasian faktor produksi yang digunakan akan berpengaruh pada produksi dan produktivitas, serta akan memberikan gambaran mengenai tingkat efisiensi yang dicapai oleh petani. Kemampuan dalam mengkombinasikan penggunaan faktor produksi secara teknis pada tingkat biaya minimum akan berpengaruh terhadap efisiensi dari pelaku usaha atau petani. Jika secara teknis proses produksi dilakukan secara tidak efisien, maka akan berdampak pada ketidakberhasilan mewujudkan produktivitas maksimal. Faktor produksi pada budidaya padi antara lain: lahan, benih, pupuk, pestisida, dan tenaga kerja. Apabila petani masih belum mampu mengalokasikan secara optimal semua faktor produksi yang ada dalam proses produksi usahatani padi sawah dan petani belum mengetahui faktor produksi mana yang alokasi penggunaannya sudah optimum, maka hal ini akan berpengaruh 
terhadap biaya produksi dan pendapatan petani. Berdasarkan latar belakang tersebut, maka peneliti tertarik pada efisiensi penggunaan faktor produksi usahatani untuk dapat meningkatkan produktivitas padi sawah dalam rangka memenuhi kebutuhan pasar yang juga akan berpengaruh terhadap tingkat pendapatan yang diperoleh petani.

Berdasarkan uraian yang telah dikemukakan di atas, maka tujuan dari penelitian ini adalah 1) Mengetahui keragaan usahatani padi sawah di Kecamatan Lakbok. 2) Mengidentifikasi pengaruh penggunaan faktor-faktor produksi secara bersama-sama (simultan) dan secara sendiri-sendiri (parsial) terhadap hasil produksi usahatani padi sawah di Kecamatan Lakbok. 3) Mengidentifikasi tingkat efisiensi penggunaan faktor-faktor produksi pada usahatani padi.

\section{METODE PENELITIAN}

Metode yang digunakan dalam penelitian ini adalah survey. Survey yaitu satu cara yang paling utama untuk dapat menggabungkan data primer apabila data sekunder masih belum lengkap untuk menjawab suatu pertanyaan (Mubyanto dan Suratno, 1981). Pengumpulan datadata sekunder dari sejumlah unit atau sejumlah individu sehingga diperoleh informasi sebanyak mungkin dalam jangka waktu bersamaan melalui alat pengukur berupa wawancara secara mendalam disebut dengan teknik survey. Penelitian ini diukur berdasarkan satu atau lebih variabel dalam sampel atau populasi yang berangkat dari data yang diperoleh berdasarkan pengamatan atau observasi (Sugiyono, 2009).

Metode pengambilan populasi menggunakan teknik Cluster Sampling yaitu pemilihan populasi yang selalu dipakai untuk dapat menentukan populasi atau sumber data yang sangat luas. Sehingga semua anggota populasi mempunyai peluang sama untuk dipilih sebagai populasi (Sugiyono, 2014). Penarikan populasi menggunakan rumus slovin. Populasi pada penelitian ini adalah petani padi sawah di Kecamatan Lakbok Kabupaten Ciamis. Teknik yang digunakan untuk pengambilan responden adalah menurut rumus Slovin dalam Sugiyono (2014), dengan populasi sebanyak 3.580 petani (e:0,10) maka diperoleh responden sebanyak 98 petani.

Data yang dipakai dalam penelitian ini adalah data primer dan data sekunder, data primer diperoleh dengan cara pengambilan data secara langsung dilakukan dengan melakukan wawancara 
kepada narasumber atau informan serta responden yang terkait dalam penelitian ini yaitu petani padi sawah sebanyak 98 orang, di Desa Sukanagara sebanyak 53 orang petani padi sawah dan di Desa Kalapasawit sebanyak 45 orang petani padi sawah yang dibantu kuesioner.

Untuk mengetahui besarnya biaya, penerimaan, pendapatan dan $\mathrm{R} / \mathrm{C}$ menggunakan rumus Soekartawi (2002). Fungsi produksi untuk usahatani padi di lahan rawa diasumsikan mempunyai bentuk Cobb Douglas yang ditransformasikan ke dalam bentuk linier logaritma natural yang dilanjutkan dengan analisis efisiensi

$\log \mathrm{Y}=\log b_{0}+b_{1} \log X_{1}+b_{2} \log X_{2}+$ $b_{3} \log X_{3}+\ldots+b_{\mathrm{i}} \log X_{\mathrm{i}}+\log \mathrm{e}$

Keterangan :

$\mathrm{Y}=$ Produksi

$\mathrm{X}_{1}, . . \mathrm{Xi}=$ Faktor produksi, meliputi pupuk Urea (kg), Benih (kg), Luas lahan (ha), pupuk ZA (kg), pupuk Organik (kg), pupuk KCL (kg), pupuk SP-36 (kg), Pestisida (Rp), dan Tenaga kerja (HOK)

$$
\begin{array}{ll}
b_{0} & =\text { Intersept } \\
b_{i} & =\text { Koefisien regresi } \\
\mathrm{e} & =\text { Koefisien regresi }
\end{array}
$$

Untuk melihat tingkat efisiensi faktor produksi dapat dianalisis dengan menggunakan analisis efisiensi ekonomi faktor produksi, yaitu Nilai Produk Marginal (NPM) dan harga faktor produksi, yaitu analisis nilai $b_{i}$. Menurut Sudarsono (1983), bi merupakan indeks efisiensi yang mencerminkan hubungan antara kuantitas produksi dengan seluruh faktor produksi. Pendekatan ini diperoleh dengan membandingkan setiap nilai produk marginal dengan harga input dengan ketentuan nilainya harus sama dengan satu, yaitu:

$$
\frac{N P M x_{1}}{H x_{1}}=\frac{N P M x_{2}}{H x_{2}}=\frac{N P M x_{3}}{H x_{3}}=1
$$

NPM : Nilai Produk Marginal

$\mathrm{Hx}$ : Harga input

Nilai produk marginal (NPM) dapat dihitung dengan menggunakan persamaan:

$$
N P M=\frac{b_{i} \cdot y}{x_{i}} \times H_{y}
$$

Dimana:

$b_{i} \quad$ : koefisien regresi

Hy : harga satuan produksi

y : hasil produksi

$\mathrm{X}_{\mathrm{i}} \quad$ : faktor produksi ke- $\mathrm{i}$

i $: 1,2,3, \ldots, n$

Penentuan efisiensi faktor produksi dengan menggunakan rasio antara nilai satu unit faktor produksi $(\mathrm{Hx})$ dengan nilai produk marginal (NPM), dengan ketentuan: 1) $\mathrm{NPM}_{\mathrm{Xi}} / \mathrm{H}_{\mathrm{xi}}=1$, Menunjukkan penggunaan variabel produksi dikatakan efisien. 2) $\mathrm{NPM}_{\mathrm{Xi}} / \mathrm{H}_{\mathrm{xi}}$ $>1$, Menunjukkan penggunaan variabel produksi belum efisien. 3) $\mathrm{NPM}_{\mathrm{Xi}} / \mathrm{H}_{\mathrm{xi}}<$ 
1, Menunjukkan penggunaan variabel produksi tidak efisien.

\section{HASIL DAN PEMBAHASAN}

\section{Keragaan Usahatani}

\subsubsection{Persemaian}

Jumlah benih yang digunakan oleh petani di daerah penelitian per hektar rata-rata sebanyak $40-45 \mathrm{~kg}$. Jika ditinjau dari jumlah benih yang seharusnya anjuran Dinas Tanaman Pangan dan Hortikultura bersama BP3K Kecamatan Lakbok Kabupaten Ciamis yaitu sebanyak sekitar $25 \mathrm{~kg}$ per hektar, penggunaan benih oleh petani dapat dikatakan berlebih dari standar seharusnya. Hal ini dilakukan untuk mengantisipasi jika terjadi banjir dan serangan hama, sehingga sisa benih digunakan untuk menyulam tanaman, terkadang petani melakukan penanaman ulang karena lahan rawa sering terkena banjir dan semua tanaman padi mati. Benih yang digunakan oleh petani adalah benih varietas lokal karena varietas hibrida dipandang tidak cocok dengan spesifik lahan. Petani menuturkan pernah beberapa kali menggunakan benih hibrida tapi hasilnya tidak memuaskan bahkan gagal panen, dan varietas lokal dipandang lebih tahan terhadap serangan hama dan penyakit.

\section{Pengolahan lahan}

Pengolahan lahan dilakukan dengan menggunakan cangkul karena di lahan rawa rata-rata memiliki struktur tanah yang lembek dan lumpur yang dalam, dan tidak mungkin memaksakan menggunakan traktor. Biaya pengolahan tanah dengan cara dicangkul sebesar Rp.1.100.000,00 per hektar dan membutuhkan tenaga kerja sebanyak 22 HOK.

\section{Penanaman}

Penanaman dilakukan dengan menggunakan bibit lokal, yang berumur dari 20-25 Hari Setelah Tanam (HST). Maksud dari penanaman bibit tersebut yaitu agar tanaman tidak habis oleh hama terutama keong dan petani beranggapan bibit yang sudah berumur cukup tua akan tahan terhadap banjir ketimbang benih muda yang berumur kurang dari 20 hari. Jumlah bibit yang ditanam perumpun yaitu 4-6 bibit.

\section{Pemupukan}

Dari hasil penelitian, seluruh petani melakukan pemupukan padi sawah dengan menggunakan pupuk kimia. Dengan anjuran dosis mengacu baku teknis dari penyuluh pertanian, meski belum semua petani menggunakan dosis sesuai anjuran. 


\section{Pemeliharaan}

\section{Pemeliharaan tanaman yang meliputi pengairan, penyiangan dan pengendalian hama dan penyakit dilakukan oleh petani di daerah penelitian berdasarkan kondisi yang ada. Pengendalian hama dan penyakit hanya dilakukan jika dalam tanaman padi tersebut terlihat ada serangan hama atau penyakit. Jika tidak ada tanda-tanda tanaman tersebut diserang maka pengendalian hama tidak dilakukan. Penyemprotan pestisida bertujuan untuk pengendalian hama dan penyakit hanya dilakukan jika di area penanaman terdapat gejala tanaman terserang, jika petani merasa tanaman padi sudah cukup terganggu dengan adanya gejala penyakit maka mereka melakukan penyemprotan.}

\section{Pemanenan}

Pemanenan dilakukan setelah tanaman berumur antara 115-125 HST. Pemanenan dilakukan dengan memotong batang padi dengan menggunakan arit bergerigi. Di daerah penelitian pemanenan masih dilakukan dengan cara sederhana hanya dengan menggunakan batu atau papan sebagai alat untuk merontokkan padi, belum menggunakan alat seperti pedal tresher. Dari hasil wawancara pemanenan tidak menggunakan alat karena lokasi panen yang sulit untuk dijangkau alat tersebut (tidak praktis jika membawa alat pedal tresher).

\section{Penggunaan Sarana Produksi Usahatani Padi}

Sarana produksi merupakan hal yang sangat dibutuhkan dalam menjalankan suatu kegiatan usahatani. Sarana produksi yang digunakan petani untuk usahatani padi sawah terdiri atas lahan, benih, pupuk kimia (Urea, KCL dan NPK), pestisida, fungisida, insektisida, tenaga kerja dan peralatan usahatani.

1. Penggunaan Lahan

Lahan merupakan input yang sangat penting dalam kegiatan usahatani padi. Lahan digunakan untuk budidaya dalam usahatani padi. Pada umumnya kepemilikan lahan petani di daerah penelitian adalah berlahan sempit yaitu di bawah satu hektar dengan status kepemilikan dan penggarap. Kepemilikan lahan yang sempit dipengaruhi beberapa faktor antara lain adanya sistem pembagian warisan, sehingga kepemilikan lahan menjadi sempit.

2. Penggunaan Benih

Benih yang digunakan adalah benih padi varietas lokal (varietas ngaos). Petani di daerah penelitian menggunakan benih ini karena benih padi varietas ini 
dianggap cocok dengan kondisi lahan dan tahan terhadap serangan hama dan penyakit. Petani menggunakan benih dari musim tanam sebelumnya dengan kualitas yang bagus, karena petani akan melakukan perawatan lebih pada padi yang akan digunakan untuk benih, tidak jarang petani membeli benih padi dari sesama petani jika hasil produksi padi miliknya berkualitas kurang baik.

\section{Penggunaan Tenaga Kerja}

Tenaga kerja yang digunakan adalah tenaga kerja pria dan wanita. Penggunaan tenaga kerja dalam usahatani padi ini menggunakan satuan Hari Orang Kerja (HOK) dengan rata-rata melakukan aktivitas selama enam jam per hari, yaitu mulai pukul 06.00-12.00 WIB. Pembayaran upah tenaga kerja dibedakan berdasarkan jenis kelamin karena ada perbedaan kapasitas pekerjaan yang dibebankan. Upah yang diberikan setiap satu hari kerja yaitu Rp 50.000 untuk pria dan Rp 40.000 untuk tenaga kerja wanita.

\section{Penggunaan Peralatan}

Peralatan merupakan sarana penunjang kegiatan usahatani yang perlu dimiliki oleh petani. Peralatan yang dimiliki oleh petani padi antara lain: cangkul, golok, sabit, dan sabit gerigi. Peralatan pertanian tersebut diperoleh dari kios saprotan (sarana produksi pertanian). Peralatan yang digunakan oleh petani sangat berpengaruh terhadap biaya tetap yang akan dikeluarkan oleh petani yaitu pada biaya penyusutan.

\section{Penerimaan Usahatani Padi Sawah}

Penerimaan usahatani padi sawah terdiri dari penerimaan tunai dan total. Total produksi rata-rata petani responden mencapai 3.566,63 kilogram per musim tanam per hektar. Harga jual padi pada saat panen Rp 4.500 per kilogram. Ratarata penerimaan tunai dan penerimaan total usahatani padi yang diperoleh petani responden per musim tanam per hektar sebesar Rp 16.049.823,11.

6. Biaya Usahatani Padi Sawah

Pengeluaran usahatani padi sawah yaitu biaya yang dikeluarkan oleh petani responden meliputi benih, Urea, KCL, NPK, pestisida, fungisida, insektisida dan tenaga kerja, penyusutan alat dan pajak lahan. Biaya yang dikeluarkan petani sebesar Rp 8.920.583,26 per musim tanam per hektar.

Biaya usahatani padi sawah terdiri atas biaya tetap dan biaya variabel. Biaya tetap (fixed cost) adalah biaya yang besar kecilnya tidak dipengaruhi oleh besar kecilnya produksi, sedangkan biaya variabel (variabel cost) adalah biaya yang besar kecilnya dipengaruhi oleh 
besar kecilnya produksi dan sifatnya habis dalam satu kali proses produksi.

Rata-rata biaya total usahatani padi sawah yang dikeluarkan oleh petani responden adalah sebesar Rp 9.005.541 per ha pada musim pertama, yang terdiri dari biaya tetap sebesar $\mathrm{Rp} 507.006,10$ dan biaya variabel sebesar $\mathrm{Rp}$ $8.498 .535,10$. Biaya tetap dalam usahatani padi sawah tersebut meliputi pajak bumi dan bangunan (PBB), penyusutan alat serta bunga modal tetap. Sedangkan biaya variabel meliputi biaya pembelian benih, pupuk kimia, obat, tenaga kerja dan bunga modal variabel.

7. Pendapatan Usahatani Padi Sawah

Rata-rata produksi padi sawah per hektar per satu musim tanam adalah 3.600,00 kilogram, harga jual padi sawah pada saat penelitian adalah $\mathrm{Rp} 4.500,00$ per kilogram, maka rata-rata penerimaan usahatani padi sawah per hektar per satu musim tanam adalah Rp 16.202.678,57.

Rata-rata biaya yang dikeluarkan dalam melaksanakan usahatani padi sawah di Kecamatan Lakbok adalah sebesar Rp. 9.005.541,20 per hektar per satu musim tanam. Pendapatan usahatani padi sawah merupakan selisih antara penerimaan yang diperoleh dengan biaya yang dikeluarkan dalam melaksanakan usahatani di Kecamatan Lakbok tersebut, dengan demikian pendapatan usahatani padi sawah sebesar Rp. 7.197.137,37 per hektar per satu musim tanam.

\section{R/C Ratio}

Rata-rata $\mathrm{R} / \mathrm{C}$ yang dihasilkan dari pelaksanaan usahatani padi sawah Kecamatan Lakbok Kabupaten Ciamis adalah sebesar 1,80 per musim tanam, artinya untuk setiap satu rupiah biaya yang dikeluarkan dalam melaksanakan usahatani padi sawah akan menghasilkan penerimaan sebesar 1,80 rupiah sehingga pendapatan atau keuntungan yang diperoleh dalam melaksanakan usahatani padi sawah di Kecamatan Lakbok Kabupaten Ciamis sebesar 0,80 rupiah. Hal tersebut berarti bahwa usahatani padi masih dapat dikatakan memberikan keuntungan untuk diusahakan bila dilihat dari segi ekonomi. Menurut Soekartawi (2002), semakin besar rasio $\mathrm{R} / \mathrm{C}$ maka akan semakin besar pula keuntungan yang diperoleh petani. Hal tersebut dapat dicapai bila petani mampu mengalokasikan faktor produksi dengan lebih efisien.

\section{Pengaruh Faktor Produksi}

1. Analisis Simultan

Analisis simultan digunakan untuk menyatakan bahwa variabel independen yang terdiri atas luas lahan, benih, pupuk, 
pestisida, insektisida, fungisida, dan tenaga kerja berpengaruh terhadap hasil produksi usahatani padi lahan rawa di Kecamatan Lakbok. Dilihat dari persamaan $\quad \tilde{\mathrm{Y}}=\mathrm{a}+\mathrm{b}_{1} \mathrm{X}$ maka akan terlihat adanya hubungan negatif dan positif antara $\mathrm{Y}$ dan $\mathrm{X}$ dimana makin besar harga jual dibandingkan input produksi atau sebaliknya. Namun diartikan jumlah variabel $\mathrm{X}$ adalah lebih dari satu. Maka koefisien tersebut diartikan dalam keadaan ceteris paribus, artinya variabel lain dianggap konstan. Untuk mengetahui besaran $F$ yaitu perbandingan antara besarnya ragam yang diduga dari sumber variasi diantara rata-rata dan sumber variasi di dalam sampel sebanyak 98. Sedangkan analisis yang digunakan saat ini untuk menentukan besaran $\mathrm{F}$ atau yang disebut juga analisis of varian (ANOVA) dapat disajikan pada Tabel 1.

Tabel 1. Tabel Anova

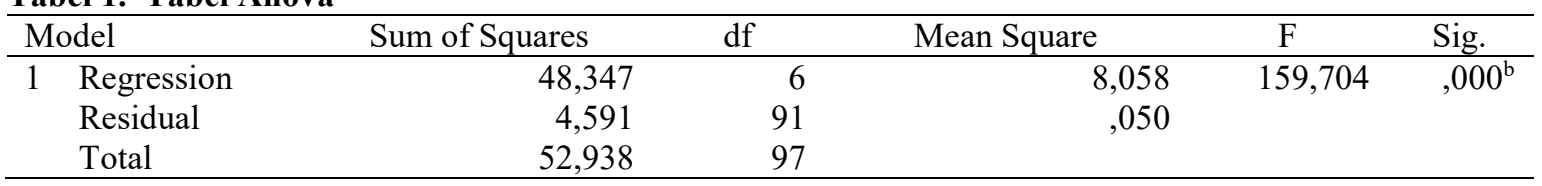

Tabel 1 menunjukan hasil pengujian statistik dengan menggunakan fungsi produksi Cobb-Douglas penggunaan faktor produksi luas lahan, benih, pupuk, dan pestisida secara simultan berpengaruh positif terhadap hasil produksi usahatani padi sawah lahan rawa di Kecamatan Lakbok dengan asumsi bahwa faktor lain tetap (ceteris paribus). Hal itu dapat dilihat pada tabel anova yang menunjukkan significant 0,000 yang masih berada dibawah toleransi 0,05. Dengan demikian maka keputusan statistiknya adalah $\mathrm{H}_{1}$ diterima dan Ho ditolak (significant).

Nilai $\mathrm{R}^{2}$ adalah sebesar 0,913 . Hal ini dapat diartikan bahwa variabel independen (luas lahan, benih, pupuk, pestisida, fungisida, insektisida dan tenaga kerja) dapat menjelaskan variabel dependen (produksi padi) sebesar 90,8 persen, sedangkan sisanya diterangkan oleh faktor lain di luar model yang diturunkan. Sedangkan nilai koefisisen korelasi diperoleh nilai sebesar 0,956 artinya keeratan hubungan antara variabel independen dan variabel dependen sebesar 95,6 persen.

2. Analisis Parsial

Dalam persamaan regresi, nilai koefisien masing-masing variabel independen (luas lahan, benih, pupuk, pestisida, fungisida, insektisida dan tenaga kerja) harus melalui pengujian 
secara satu persatu. Hal ini bertujuan untuk mengetahui variabel independen mana yang memiliki pengaruh nyata terhadap variabel dependen. Uji signifikan merupakan salah satu bagian dalam analisis regresi linier, apabila signifikan $\mathrm{t}$ yang digunakan sebagai ukuran, maka nilai signifikansi t tersebut harus dibandingkan dengan tingkat alpha $(\alpha=0,05)$. Apabila $\mathrm{t}$ hitung $>$ Sig, maka dikatakan signifikan. Namun apabila $\mathrm{t}$ hitung $\leq$ Sig, maka dinyatakan tidak signifikan. Untuk lebih jelasnya hasil analisis dari ketujuh faktor-faktor produksi tersebut dilihat pada Tabel 2 .

Tabel 2. Analisis Parsial pada Usahatani Padi Kecamatan Lakbok

\begin{tabular}{|c|c|c|c|c|c|c|}
\hline \multirow{2}{*}{\multicolumn{2}{|c|}{ Model }} & \multicolumn{2}{|c|}{ Unstandardized Coefficients } & \multirow{2}{*}{$\begin{array}{c}\text { Standardized Coefficients } \\
\text { Beta } \\
\end{array}$} & \multirow[b]{2}{*}{$\mathrm{t}$} & \multirow[b]{2}{*}{ Sig } \\
\hline & & B & Beta & & & \\
\hline \multirow[t]{8}{*}{1} & (Constant) & 6,962 & 502 & & 13,876 &, 000 \\
\hline & LAHAN &, 731 & 076 & & 9,558 &, 000 \\
\hline & BENIH &,- 024 &, 044 & &,- 548 &, 585 \\
\hline & PUPUK &, 007 &, 059 & &, 116 & ,908 \\
\hline & PESTISIDA &,- 038 & 035 & & $-1,069$ & ,288 \\
\hline & FUNGISIDA &, 030 & 053 & &, 568 &, 572 \\
\hline & INSEKTISIDA & 057 & 054 & & 1,046 & ,298 \\
\hline & TENAGA KERJA & 274 &, 124 & & 2,199 & 030 \\
\hline
\end{tabular}

Tabel 2 menunjukkan bahwa terjadi multikolinearitas tinggi pada variabel tenaga kerja sehingga variabel tersebut dihilangkan dari model dan dilakukan pengujian ulang dengan menghilangkan variabel tenaga kerja pada (Soekartawi, 1993) dapat dilihat pada Tabel 3.

Tabel 3. Analisis Parsial Usahatani Padi Kecamatan Lakbok yang telah dihilangkan multikolinieritasnya

\begin{tabular}{|c|c|c|c|c|c|c|}
\hline \multirow{2}{*}{\multicolumn{2}{|c|}{ Model }} & \multicolumn{2}{|c|}{ Unstandardized Coefficients } & \multirow{2}{*}{$\frac{\text { Standardized Coefficients }}{\text { Beta }}$} & \multirow[b]{2}{*}{$\mathrm{t}$} & \multirow[b]{2}{*}{ Sig. } \\
\hline & & $\mathrm{B}$ & Beta & & & \\
\hline \multirow[t]{7}{*}{1} & (Constant) & 7,824 & ,320 & & 24,481 & 000 \\
\hline & LAHAN &, 842 & 059 & ,819 & 14,335 &, 000 \\
\hline & BENIH &, 029 &, 037 & 037 & ,782 & ,436 \\
\hline & PUPUK &, 053 &, 056 & 048 & ,936 & ,352 \\
\hline & PESTISIDA & 044 & ,036 &,- 052 & $-1,245$ & 216 \\
\hline & FUNGISIDA &, 061 &, 052 &, 068 & 1,167 & ,246 \\
\hline & INSEKTISIDA &, 073 &, 055 & 067 & 1,316 & 191 \\
\hline
\end{tabular}

a. Dependent Variable: PRODUKSI

Berdasarkan Tabel 3 dapat diketahui hasil analisis statistik secara parsial menunjukkan, dari 6 (enam) faktor produksi yang diteliti ternyata penggunaan faktor produksi lahan berpengaruh signifikan terhadap hasil produksi usahatani padi karena tingkat signifikansinya berada dibawah 0,05. Dengan demikian maka keputusan statistiknya adalah $\mathrm{H}_{1}$ diterima dan $\mathrm{Ho}$ 
ditolak (significant). Sedangkan penggunaan faktor produksi benih, faktor produksi pupuk, faktor produksi pestisida, faktor produksi fungisida, dan faktor produksi insektisida tidak berpengaruh signifikan terhadap hasil produksi usahatani padi. Hal itu dapat dilihat pada tabel yang menunjukkan tingkat significant 0,436 untuk faktor produksi benih, 0,352 untuk faktor produksi pupuk, 0,216 untuk faktor produksi pestisida, 0,246 untuk faktor produksi fungisida, dan 0,191 untuk faktor produksi insektisida yang berada di atas toleransi 0,05. Dengan demikian maka keputusan statistiknya adalah Ho diterima dan $\mathrm{H}_{1}$ ditolak (tidak significant).

\section{Efisiensi Faktor Produksi}

Soekartawi

(1993)

dalam

terminologi ilmu ekonomi, mengemukakan bahwa efisien dapat digolongkan menjadi 3 (tiga) macam, yaitu: efisiensi teknis, efisiensi alokatif (efisiensi harga) dan efisiensi ekonomi. Suatu penggunaan faktor produksi yang dipakai menghasilkan produksi yang maksimum. Dikatakan efisiensi harga atau efisiensi alokatif kalau nilai dan produk marginal sama dengan harga faktor produksi yang bersangkutan dan dikatakan efisiensi ekonomi kalau usaha pertanian tersebut mencapai efisiensi teknis dan sekaligus juga mencapai efisiensi alokatif atau harga. Atau suatu proses produksi secara ekonomi dikatakan sudah efisien apabila dalam proses produksi tersebut perbandingan antara nilai produk marginal (NPM) dengan biaya korbanan marginal (BKM) sama dengan satu untuk seluruh faktor produksi yang digunakan. Pada kondisi ini dikatakan pula bahwa pemakaian faktor produksi berada pada keadaan optimum (Teken dan Asnawi, 1977 dalam Lutfiadi, 2010).

Seorang petani secara teknis dikatakan lebih efisien (efisiensi teknis) dibandingkan dengan yang lain bila petani itu dapat berproduksi lebih tinggi secara fisik dengan menggunakan faktor produksi yang sama. Sedangkan efisiensi harga dapat dicapai oleh seorang petani apabila dapat memaksimumkan keuntungan (mampu menyamakan nilai marginal produk setiap faktor produksi variabel dengan harganya).

Menurut Nicholson (1995) efisiensi ekonomi digunakan untuk menjelaskan situasi sumber-sumber dialokasikan secara optimal. Efisiensi ekonomi terdiri atas dua komponen yaitu efisiensi teknis (technical efficiency) dan efisiensi harga 
atau efisiensi alokatif (price efficiency or allocative efficiency)

Efisiensi teknis mengukur berapa produksi yang dapat dicapai suatu input tertentu. Besarnya produksi tersebut menjelaskan keadaan pengetahuan teknis dan modal tetap yang dikuasai oleh petani atau produsen. Suatu usaha dikatakan lebih efisien secara teknis jika dengan menggunakan input yang sama produk yang dihasilkan lebih tinggi. Efisiensi teknis juga sering disebut efisiensi jangka panjang. Sedangkan efisiensi harga (alokatif) berhubungan dengan keberhasilan petani dalam mencapai keuntungan maksimum. Efisiensi ini disebut juga efisiensi jangka pendek.

Menurut Doll dan Orazem (1984), untuk mencapai keuntungan yang maksimal, suatu usahatani harus memenuhi dua syarat yaitu syarat keharusan (Necessary Condition) dan syarat kecukupan (Sufficient Condition). Syarat keharusan (Necessary Condition) dipenuhi pada saat tidak ada lagi kemungkinan lain dalam penggunaan input yang lebih sedikit untuk menghasilkan nilai produksi yang sama, atau ketika elastisitas produksi lebih besar atau sama dengan nol dan lebih kecil atau sama dengan satu $(0 \leq \mathrm{ep} \leq 1)$.
Dalam melakukan usahatani, analisis efiensi diperlukan agar dalam penggunaan sarana produksi petani tidak melakukan pemborosan. Petani yang rasional akan berprinsip bagaimana dalam proses produksinya bisa mencapai tingkat efisiensi ekonomi yang maksimum. Konsep ini bisa diterapkan apabila petani dalam mengusahakan usahataninya bebas dari berbagai kendala atau keterbatasan. Namun kenyataannya petani berada dalam kondisi dengan berbagai kendala, maka yang dapat dilakukan petani adalah membawa proses produksinya untuk mencapai kondisi yang seefisien mungkin.

Efisiensi ekonomi merupakan pedoman bagi petani dalam melakukan faktor-faktor produksi, sehingga dapat mencapai keuntungan maksimum. Dalam usahatani dimaksudkan agar petani mengalokasikan sumberdaya yang ada secara efektif dan efisien untuk tujuan memperoleh keuntungan yang tinggi. Efisiensi ekonomi tertinggi akan menunjukkan bahwa produksi yang dihasilkan dalam suatu usahatani sudah mencapai keuntungan yang maksimal.

Berbeda dengan syarat keharusan yang objektif, syarat kecukupan dapat berbeda pada setiap usahatani atau individu dan merupakan efisiensi yang 
subjektif. Terpenuhi atau tidaknya kedua syarat tersebut dapat diketahui dengan menggunakan sebuah persamaan yaitu perbandingan antara Value Marginal Product (PyMPxi) atau disebut juga Nilai Produk Marjinal (NPMXi), dan Marginal Factor Cost (MFC) atau yang sering disebut dengan Biaya Korbanan Marjinal (BKM). Nilai Produk Marjinal merupakan hasil kali antara harga produk dengan Produk Marjinal (PM) sementara Biaya Korbanan Marjinal (BKM) sama dengan harga representatif dari faktor produksi yang digunakan.

Tingkat efisiensi ekonomis dari penggunaan faktor-faktor produksi dapat dilihat dari besarnya rasio Nilai Produk Marjinal dengan Biaya Korbanan Marjinal per periode produksi. Faktorfaktor produksi yang dapat di analisis adalah faktor- faktor produksi yang bersifat fisik dan yang dapat dinilai dengan rupiah. Jika rasio NPM dengan
BKM lebih besar dari satu, maka penggunaan faktor-faktor produksi disebut belum efisien dan perlu ditingkatkan penggunaannya untuk mencapai keuntungan maksimum. Rasio NPM dengan BKM yang lebih kecil dari satu menunjukkan bahwa penggunaan faktor-faktor produksi telah melebihi batas optimal sehingga untuk mencapai keuntungan maksimum maka penggunaannya harus dikurangi.

Rasio NPMXi dengan BKMXi yang sama dengan satu untuk semua faktorfaktor produksi menunjukkan bahwa penggunaan faktor- faktor produksi dalam usahatani tersebut tepat berada pada kondisi optimal dan telah mencapai keuntungan maksimum sehingga usahatani dapat dikatakan telah efisien secara ekonomis. Rasio NPMXi dengan BKMXi usahatani padi sawah di Kecamatan Lakbok disajikan dalam Tabel 4.

\begin{tabular}{lrrrrrr} 
Tabel 4. Taksiran Besarnya Rasio Nilai Produk Marginal Dengan Harga Faktor Produksi Pada Usahatani Padi \\
\hline $\begin{array}{c}\text { Faktor } \\
\text { produksi }\end{array}$ & $\begin{array}{c}\text { Elastisitas } \\
\text { produksi (bi) }\end{array}$ & $\begin{array}{c}\text { Produk } \\
\text { rata-rata }\end{array}$ & \multicolumn{1}{c}{ Produk marginal } & NPMXi & BKMXi & $\frac{N P X i}{B K M X i}$ \\
\hline Luas Lahan & 0,8420 & 0,4543 & $3.003,0059(\mathrm{ha})$ & 18018035,2868 & 10.500 .000 & 1,4300 \\
Benih & 0,0290 & 35,1054 & $1,3385(\mathrm{~kg})$ & 8030,8618 & 14.000 & 0,0006 \\
Pupuk & 0,0530 & 130,1286 & $0,6599(\mathrm{~kg})$ & 3959,5077 & 2.500 & 0,0003 \\
Pestisida & 0,0440 & 3,8827 & $18,36,7492(\mathrm{ml})$ & 110168,3688 & 45.000 & 0,0087 \\
Fungisida & 0,0610 & 0,2263 & $436,7492(\mathrm{ml})$ & 2620495,1454 & 30.000 & 0,2080 \\
Insektisida & 0,0730 & 0,2314 & $511,1476(\mathrm{ml})$ & 3066885,6534 & 35.000 & 0,2434 \\
\hline
\end{tabular}

Tabel 4 menunjukkan penggunaan faktor-faktor produksi aktual dan rasio Nilai Produk Marjinal (NPMXi) dengan
Biaya Korbanan Marjinal (BKMXi) pada usahatani padi sawah di Kecamatan Lakbok. Rasio NPMXi/ BKMXi dari 
setiap faktor produksi menunjukkan bahwa penggunaan faktor-faktor produksi dalam usahatani padi sawah di Kecamatan Lakbok tidak efisien secara ekonomis, karena nilai-nilai rasio NPMXi/BKMXi tidak ada yang sama dengan satu. Rasio ini juga berarti bahwa penggunaan faktor-faktor produksi pada usahatani padi sawah belum optimal pada jumlah produksi 3.600,60 Kg per hektar. Pada Tabel 21 dapat dilihat bahwa rasio NPMXi dan BKMXi untuk faktor benih, pupuk, pestisida fungisida dan insektisida masing-masing kurang dari satu. Nilai rasio ini mengandung arti bahwa penggunaan faktor-faktor produksi tersebut masih kurang dan masih dapat ditingkatkan lagi agar dicapai tingkat penggunaan yang efisien atau optimal. Penggunaan faktor produksi pestisida dan pupuk yang rendah ini disebabkan oleh keterbatasan modal yang dimiliki petani untuk membeli pupuk dan pestisida dalam jumlah yang lebih besar yang sesuai dengan kebutuhan usahatani berdasarkan kondisi kesuburan dan kandungan hara tanah, sehingga pupuk, pestisida fungisida dan insektisida hanya digunakan berdasarkan kemampuan finansial petani. Penggunaan benih yang tidak efisien juga disebabkan oleh ketidakmampuan petani secara finansial untuk membeli benih, sehingga benih yang digunakan responden adalah benih yang merupakan hasil pembungaan sendiri dengan mutu yang lebih rendah dari pada benih komersial.

Rasio NPMXi dan BKMXi yang paling kecil adalah pada faktor produksi pupuk yaitu sebesar 0,2092. Berdasarkan nilai rasio ini, maka penggunaan pupuk memerlukan penambahan yang relatif lebih besar agar dicapai tingkat efisien. Rendahnya penggunaan pupuk disebabkan karena aplikasi penggunaan pestisida yang kurang tepat dan harga yang relatif tinggi. Nilai efisiensi ekonomi luas lahan lebih dari satu, artinya kombinasi penggunaan faktor pada usahatani padi sawah belum mencapai efisiensi ekonomi.

\section{KESIMPULAN DAN SARAN}

Berdasarkan hasil pembahasan sebelumnya, dapat ditarik beberapa kesimpulan, yaitu sebagai berikut:

1. Keragaan pada usahatani padi lahan rawa di Kecamatan Lakbok sebagai berikut: Rata-rata biaya total yang dikeluarkan oleh petani responden adalah sebesar Rp. 9.005.541 per ha pada musim pertama, yang terdiri dari biaya tetap sebesar Rp. 507.006,10 dan biaya variabel sebesar Rp. 
8.498.535,10, dengan rata-rata produksi padi sawah lahan rawa per hektar per satu musim tanam adalah 3.600,00 kilogram, dengan harga jual Rp 4.500,00 per kilogram, maka memperoleh penerimaan $\mathrm{Rp}$ 16.202.678,57 dan rata-rata pendapatan usahatani padi sawah lahan rawa per hektar per satu musim tanam sebesar Rp 7.191.137,37. Berdasarkan analisis pendapatan usahatani padi sawah lahan rawa di Kecamatan Lakbok dikatakan layak diusahakan, hal ini dapat dilihat pada nilai $\mathrm{R} / \mathrm{C}$ rasio lebih dari satu yaitu 1,80 .

2. Secara simultan dapat dinyatakan bahwa penggunaan faktor produksi yaitu luas lahan, benih, pupuk, pestisida, fungisida, insektisida berpengaruh positif terhadap hasil produksi usahatani padi lahan rawa di Kecamatan Lakbok dengan asumsi bahwa faktor lain tetap (ceteris paribus), sedangkan secara parsial menunjukkan, dari 6 (enam) faktor produksi yang diteliti ternyata penggunaan faktor produksi lahan, dan berpengaruh signifikan terhadap hasil produksi usahatani padi karena tingkat signifikansinya berada dibawah 0,05, untuk penggunaan faktor produksi benih, faktor produksi pupuk, faktor produksi pestisida, faktor produksi fungisida, dan faktor produksi insektisida tidak berpengaruh signifikan terhadap hasil produksi karena tingkat signifikansinya berada di atas 0,05 . Variabel-variabel atau faktor-faktor produksi pada usahatani padi tersebut belum efisien dalam penggunaannya. Hal ini karena nilai rasio NPM/BKM lebih besar dari satu dan kurang dari satu sehingga penggunaan aktual dari input tersebut ada yang harus ditambah dan dikurangi untuk mencapai penggunaan input optimal.

3. Nilai efisiensi ekonomi, luas lahan, fungisida, insektisida, fungisida kurang dari satu, artinya kombinasi penggunaan faktor produksi yang berupa luas lahan, fungisida, insektisida, pestisida dan pada usahatani padi sawah lahan rawa belum mencapai efisiensi ekonomi tertinggi. Sedangkan nilai efisiensi ekonomi untuk faktor produksi benih, pestisida, fungisida, insektisida menunjukkan angka kurang dari satu, artinya penggunaan faktor produksi tersebut pada usahatani padi sawah lahan rawa belum efisien karena masih perlu ditingkatkan agar 
mempeoleh pendapatan yang maksimal.

Berdasarkan hasil penelitian dan pembahasan pada efisiensi produksi usahatani padi sawah lahan rawa di Kecamatan Lakbok. Maka disarankan hal-hal sebagai berikut :

1. Petani sebaiknya menanam padi sawah dengan varietas lokal untuk meningkatkan produksi karena produktivitas varietas lokal lebih tinggi dibandingkan varietas unggul. Oleh sebab itu maka pendapatan usahatani padi sawah rawa akan meningkat dan didukung dengan teknologi budidaya padi sawah rawa serta penyuluhan pemberian benih yang dianjurkan Dinas Tanaman Pangan dan Hortikultura bersama BP3K Kecamatan Lakbok Kabupaten Ciamis yaitu sebanyak sekitar $25 \mathrm{~kg}$ per hektar.

2. Meningkatkan pengetahuan dan ketrampilan petani sebagai pengelola usahatani dalam tehnik budidaya padi dan pengalokasian faktor-faktor produksi secara efisien dan efektif melalui kegiatan penyuluhan..

3. Pemerintah sebaiknya melakukan penyuluhan, pendampingan teknologi budidaya padi sawah rawa, dan pengendalian hama penyakit serta

$$
\begin{aligned}
& \text { menyediakan bantuan pupuk, } \\
& \text { pestisida, dan alsintan untuk } \\
& \text { menunjang usahatani padi sawah rawa }
\end{aligned}
$$

\section{DAFTAR PUSTAKA}

Anwar, K., S. Sabiham, B. Sumawinata, A. Sapei, dan T. Alihamsyah. 2006. Pengaruh Kompos Jerami terhadap Kualitas Tanah, Kelarutan Fe2+ dan SO42- serta Produksi Padi pada Tanah Sulfat Masam. Jurnal Tanah dan Iklim No. 24/2006.

BP3K Kecamatan Lakbok. 2016. Programa Penyuluhan Pertanian. BP3K Kecamatan Lakbok.

Doll,. PJ. and, Orazem F. 1984. "Production Economics, Theory With Application". John Willey and Sons Inc. New York.

Kusnadi, N., Tinaprilla,N., Susilowati,S.H., Purwoto,A. 2011. Analisis Efisiensi Usahatani Padi di Indonesia. Jurnal Agro Ekonomi. Vol 29, No.1, Mei 2011. Pusat Sosial Ekonomi dan Kebijakan Pertanian. Kementerian Pertanian. Bogor.

Mubyarto dan Suratno. 1981. Metodologi Penelitian Ekonomi. Yayasan Agro Ekonomika. Yogyakarta.

Nicholson, W. 1995. Teori Makro Ekonomi: Prinsip Dasar dan Perluasan, Edisi Kelima. Terjemahan: Danel Wijaya. Jakarta: Bina Rupa Aksara.

Sugiyono. 2009. Metode Penelitian Kuantitatif, Kualitatif dan $R \& D$. Bandung: Alfabeta.

Sugiyono. 2014. Metode Penelitian Kuantitatif, Kualitatif, Dan Kombinasi (Mixed Metods). Bandung: Alfabeta.

Sudarsono. 1983. Pengantar ekonomi mikro. Jakarta: LP3ES. 